IJSE

48,3

Received 22 January 2020

Revised 30 August 2020

31 October 2020

13 November 2020

Accepted 16 November 2020

\section{Regional labour market effects of immigration on low-skilled workers: the case of Sweden 1990-2003}

\author{
Evans Korang Adjei \\ Center for Regional Science, Umeå University, Umeå, Sweden and \\ Arena Ide, Stockholm, Sweden \\ Lars-Fredrik Andersson \\ Unit of Economic History, Umeå University, Umeå, Sweden \\ Rikard H. Eriksson \\ Department of Geography, Umea University, Umeå, Sweden and \\ Center for Regional Science, Umeà University, Umeà, Sweden, and \\ Sandro Scocco \\ Arena Ide, Stockholm, Sweden
}

\begin{abstract}
Purpose - The purpose of this paper is to examine the effects of immigration on the labour market outcomes of low-educated natives (i.e. residents without a university diploma). Using the labour market competition theory, which argues that the labour market effects of natives depend on the skill set of immigrants, the paper addresses whether immigrants are complementary to or substitutes for native workers.

Design/methodology/approach - Longitudinal matched employer-employee data on Sweden are used to estimate how low-educated natives, in regions experiencing the greatest influx of refugees from the Balkan wars, responded to this supply shock with regard to real wages, employment and job mobility between 1990 and 2003 .

Findings - First, the analysis shows that low-educated native workers respond to the arrival of immigrants with an increase in real wages. Second, although employment prospects in general worsened for low-skilled workers in most regions, this is not attributable to the regions experiencing the largest supply shock. Third, there are indications that low-skilled natives in immigration-rich regions are more likely to change workplace, particularly in combination with moving upwards in the wage distribution.

Originality/value - Rather than seeing an emergence of the commonly perceived displacement mechanism when an economy is subject to a supply shock, the regional findings suggest that high inflows of immigrants tend to induce a mechanism that pulls native workers upwards in the wage distribution. This is important, as the proportion of immigrants is seldom evenly distributed within a nation.
\end{abstract}

Keywords Displacement, Refugee immigration, Low-skilled natives, Upgrading, Sweden

Paper type Research paper

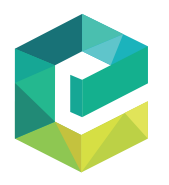

(C) Evans Korang Adjei, Lars-Fredrik Andersson, Rikard H. Eriksson and Sandro Scocco. Published by Emerald Publishing Limited. This article is published under the Creative Commons Attribution (CC BY 4.0) licence. Anyone may reproduce, distribute, translate and create derivative works of this article (for both commercial and non-commercial purposes), subject to full attribution to the original publication and authors. The full terms of this licence may be seen at http://creativecommons.org/licences/by/4.0/ legalcode

The manuscript has benefited greatly from comments received by the referees. The usual disclaimer Economics Vol. 48 No. 3,2021
pp. 456 m pp. 456-476 Emerald Publishing Limited 0306-8293

DOI 10.1108/IJSE-01-2020-0038 however applies. The research work (salaries) has been granted by Arenagruppen, Arena idé, Sweden and the Marianne and Marcus Wallenberg Foundation. The researchers have independently from the funding bodies carried out the design of the study and collection, analysis and interpretation of data. 


\section{Introduction}

Rising figures on foreign labour supply have been part of the general development in the EU15, where, according to the European Labour Force Survey, the average share of immigrants in the labour force has increased from 10.7 to $16.9 \%$ between 1995 and 2018 . Sweden is no exception. On the contrary, within the European Union (EU), Sweden stands out as one of the most prominent receivers of refugees, and one of the major changes on the Swedish labour market over the past 30 years has consequently been the growing share of foreign workers. By the mid-1990s, $8.8 \%$ of the working-age population was foreign born, while the figure today is $23.6 \%$ of the total labour force. The expansion of the labour force over this period, caused by an increase in the number of foreign born of working age from 0.5 million to 1.5 million, has been the major driver behind expansion of the total labour supply in Sweden (SCB, 2019a, 2019b).

The labour market consequences of immigration for hosting communities have become a major interest among policymakers and researchers. The impact of immigration on the labour market has been controversial. This especially concerns the extent to which the inflow of migrants helps or harms less-skilled natives. Studies on immigration in the USA have shown different findings. While Card (2009), for example, found only minor effects on wages, Borjas (2003) showed that immigration is harmful for natives' wages. In turn, Ottaviani and Peri (2012) demonstrated positive wage effects for natives.

Studies on Europe equally have presented mixed findings. In their study on the EU15 and the European Economic Area (EEA) countries in the 1980 and 1990s, Angrist and Kugler (2003) showed how immigration had a harmful effect on natives' employment rates, especially among the younger parts of the workforce. In their follow-up study on the EU15 in the 1990s and early 2000s, Amuri and Peri (2011) found less evidence for reduced employment rates among natives. Concerning the Spanish case, González and Ortega (2011) showed that unskilled immigrants did not impact the employment or wages of unskilled natives, while a study on France revealed that rising immigration actually helped improve wages and the employment rate among natives (Ortega and Verdugo, 2014). From the UK, there is evidence for a negative impact of new immigrants on previous immigration cohorts, but less of an effect on natives (Manacorda et al., 2012). In turn, a study on foreign labour inflow in German border regions identified adverse effects on natives' employment rate and wages (Dustmann et al., 2017). Similar results were found for Norway, where natives' wages in particular were responsive to inflow from neighbouring countries, but less so to inflow from developing countries (Bratsberg et al., 2014). Hence, the international literature provides rather mixed results.

As shown in a recent literature survey (Edo, 2019), Swedish evidence on the impact of immigration has been rather limited, given the influx of immigrants, and one cannot automatically assume that findings from other countries are generalisable to all countries, as institutional differences influence the extent to which the labour market is affected by immigration (Andersson et al., 2019). Sweden is one of the countries with the most notable growth in its foreign-born population during the past 30 years. In particular, refugee immigration is responsible for a growing part of the population, as Sweden is among the countries accepting the largest number of refugees in proportion to population, both during the more recent Syrian war and during the Balkan war of the 1990s.

The aim of the present paper is to examine the effects of immigration on the labour market outcomes of low-educated natives (i.e. residents without a university diploma). For this purpose, we focus on the case of Sweden in the 1990s - a period with a major influx of refugee immigration following the Balkan wars. Our reason for analysing the impact on low-educated natives is that they are the group of native workers most likely to be directly affected by an increasing exogenous labour supply. Moreover, recent studies have demonstrated the role of complementarity within education groups as well as specialisation of native workers in

\section{Regional effects of immigration}


IJSE

48,3

458

response to immigration (Ottaviano and Peri, 2012; Peri, 2012). The present study will help broaden and deepen our understanding of such mechanisms by examining groups less likely to benefit, such as less-educated natives.

While there have been manifold studies on the relationship between the arrival of immigrants and the labour market outcomes of native workers, our ability to convincingly measure the causal effects of immigrants on native workers is limited (Foged and Peri, 2015). Considering the measurement and selection problems associated with this exercise, we use longitudinal matched employer-employee data for Sweden for the period 1990-2003. The rationale for this period is twofold. First, following the Balkan wars, Sweden experienced a rapid increase in refugees from the former Yugoslavia. Compared to Foged and Peri (2015), who used a policy reform that redistributed immigrants in Denmark as an identification strategy, we use real inflows to select regional labour markets (or homogenous commuting areas: FA regions) that received the largest shares of refugees from 1993 onwards. Focusing on the regional dimension is imperative, as national figures, employed by most previous studies, cannot discern the local variation in supply change or its potential effect. Second, while the absorption of immigrants into the labour market is usually facilitated in periods of capital expansion (cf. Tabellini, 2020), this particular period coincided with a deep recession with rising unemployment figures (Eriksson and Hane-Weijman, 2017). Despite this, Ekberg (2016) showed exceptional labour market integration among Bosnian immigrants during this period, something that has not been seen for other immigration groups in other periods. Hence, compared to the period of relative growth during 2015/2016, when economic conditions were relatively more favourable, the period analysed here is characterised by a relatively low labour demand. With these data, we are not only able to identify the exact time (year) of immigrant inflows, but also follow them across time and space, and control for both short- and long-term effects of immigrants on low-skilled natives' labour market outcomes.

Our difference-in-differences estimations indicate three main findings. First, similar to other studies, our analysis shows that low-educated native workers respond to the arrival of immigrants with an increase in real wages. Second, although employment prospects in general worsened for low-skilled workers in most regions during this period, this is not attributable to the regions experiencing the largest foreign labour supply shock. Third, there are indications that low-skilled natives in immigration-rich regions are more likely to change workplace, particularly in combination with moving upwards in the wage distribution.

The remainder of the paper is organised as follows. Section 2 presents the theoretical arguments for how immigration affects low-educated natives. Section 3 describes the data, variables and empirical model. Section 4 presents the results, and section 5 presents the conclusions.

\section{Conceptual framework}

The impact of immigration on earnings and employment is often studied within the framework of standard economic models. Starting from Roy's (1951) model of occupational self-selection, it could be argued that optimal matching of skills and occupations cannot be readily assumed, as sorting into different labour market segments depends on the distribution of skills, the correlation of skills in the population and the technology available to apply the skills in a productive manner. When applying the Roy model to the case of immigrant earnings in the USA, Borjas (1987) showed that the expected income of immigrants depended on the economic and political conditions in their country of origin, hence not only the skills of each respective migrant. Thus, western Europeans immigrating to the USA would do better than those from developing countries, even if individual skills were equal. Given that immigrants originate from relatively economically buoyant countries, the supply of low-skilled or unskilled immigration is likely to harm the labour market outcomes 
of less-skilled natives (cf., Borjas, 1987). The argument holds that an increasing supply of labour due to immigration will cause a wage reduction among native labour competing for the same jobs immigrants are seeking, especially if immigrants are supplied in a closed labour market (Borjas, 2006).

Immigration is also often thought to change the skill composition of the workforce. If immigrants have a very different skill composition than natives, which could be the case, especially in relation to a large influx of refugees, the impact of immigrants will be heterogonous across skill groups (Borjas, 2003; Ottaviano and Peri, 2012). Drawing from a competitive labour model, it is expected that immigration will lower the wages of native workers who are most similar to the immigrants due to the supply shock, while increasing the wages of groups of workers most different from the immigrants (Dustmann et al., 2016). The latter group will benefit from the improved complementary of skills, raising their marginal productivity. In turn, immigration is not expected to impact natives if the skill distribution is perfectly similar, as only labour supply will increase, keeping the relative supply of skills unchanged.

In the long run, however, the heterogeneity or homogeneity of skill composition is not expected to have an impact on mean wages in the economy (Borjas, 2003). For the native population, there will still be "winners" and "losers" as long as the skill distribution of immigrants plays a role in creating complementarity effects for some and substitution effects for others (Borjas, 2014). Nor will the accumulation of capital to the pre-immigration capital/ labour ratio resort the initial wage polarisation as long as the degree of complementarity of the real capital stock is the same for both low- and high-skilled workers.

The harmful effects are commonly associated with a reduction in wages. But, other outcomes are also likely to occur. One expected response among competing (native) workers to the influx of immigrants is to move to different regions seemingly less affected by a supply shock (Aydemir and Borjas, 2011; Borjas, 2006). Borjas (2006) even suggested that native migration flows diffuse the impact of immigration across the entire economy, hence making native internal migration decisions sensitive to immigrant-induced increases in labour supply and wages. Borjas further demonstrated that native migration explains about $40 \%$ of the gap in wage effects. The labour market competition model, thus, suggests that immigration increases the supply of a certain type of labour and that, depending on the skill sets of the immigrants and natives, this can affect not only wages but also employment and mobility. In the short run, the higher inflow of immigrants should lower the outcomes of competing workers and increase those of complementary workers (Aydemir and Borjas, 2011; Edo, 2015).

The standard models of immigration-induced labour market impacts have more recently been extended, showing that low-skilled immigration could have much less impact on lowskilled natives than previously anticipated. Akin to Roy's (1951) early notion on the role of technology, one line of argument is that firms, by changing their technology in response to immigration, mitigate the impact on native workers. This is because firms will adjust their technology to take advantage of the relatively more abundant supply of skills following immigration. By allowing capital to be complementary to high skills and supplementary to low skills, Lewis (2011) showed that firms will respond to immigration by investing in capital following an inflow of skilled workers and disinvest after an inflow of low-skilled workers. Wages will then return to pre-immigration levels when the capital stock has adjusted for the change in skill composition.

Immigrants with similar education and working experience, however, may not be perfect substitutes for native workers. Better communication abilities, cultural and social capital specific to a national context and discriminating norms tend to give native workers a competitive advantage compared to immigrants with seemingly similar skills. In theory, natives will then specialise in high-communication-intensive tasks, while immigrants will

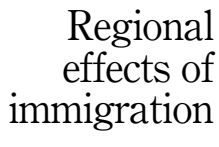

459 
IJSE

48,3 specialise low-communication-intensive work (Foged and Peri, 2015; Peri and Sparber, 2009). Any negative effect of wages would then arise among previous immigrants who are substitutes for new waves of immigrants (Manacorda et al., 2014).

The extensions from the standard model allow for an adjustment to immigration shocks through two channels, first, through investments in new capital and, second, through the occupational mobility of natives. Assuming that capital and high-skilled labour are complements, only the latter effect is expected to increase the wages and employment of natives, such as low-skilled workers taking advantage of language or other contextdependent skills.

A number of approaches are being exploited to argue for the various findings on natives' labour market outcomes. Borjas (2003) invented an approach that measures the same skill sets for natives and immigrants to enable comparisons within the same skill group. Altonji and Card (1991) used a spatial variation approach to capture the total immigrant flow across regions and examine the effect of immigration. Card (2001) later developed a variation on the spatial variation approach by allowing variation in the composition of immigrant inflows by education and region. The skill approach and the mixed approach seek to identify a relative wage/employment effect of immigration, whereas the spatial approach seeks to quantify the total wage/employment effect of immigration. Both approaches are sensitive to the assumption that foreign and native labour with the same human capital are placed in the same cell. There is a risk of measurement error concerning education and skills, but also a risk of immigrants being downgraded upon arrival, leading to misclassification. As recommended by Dustman et al. (2016), we apply the spatial approach here by assessing the total effect of immigration on a specific group of native workers (the low educated). This is done in an attempt to understand whether groups with similar characteristics are affected differently depending on whether the regional labour market is subject to a sudden supply shock of immigrants.

\section{Data}

The data used in the present study are from a matched employer-employee database covering the entire Swedish population. The database contains annual reports on firms (size, profitability, location, etc.) and on individuals (place of birth, year of immigration, age, employment status, educational level, real wages, etc.). The relational characteristics of the database allow us to link data on individuals to their workplaces and the specific industries and regions in which they work.

From this database, we focus on low-skilled Swedes selected according to the following criteria: first, selected individuals who were between 18 and 64 years old (potential labour force or working-age population, who were not attending school between 1990 and 2003). With this population of potential labour force, we further restricted our sample to workers between 20 and 50 years in 1990 to avoid right-censoring and restricting new workers from entering the group. A person will continuously be in the sample unless (s)he becomes incapacitated, retires, leaves Sweden (no longer in the Swedish tax registers) or dies during the 1990-2003 period. This restriction prevents noise caused by the entry and exit of individuals. Furthermore, we restricted our analysis of outcomes to a panel of Swedish-born individuals without a university education (three years or longer university education). As argued above, we believe that this group of natives are those who are most likely to be at immediate risk of competing with immigrants. All of these selections give a total of 1,033,028 individuals whom we can observe for the period 1990-2003 (note that, due to the factors mentioned above, we do not have a perfectly balanced panel with a total of year-person observations summing up to 11,058,364). Figure 1A displays the share of low-educated natives by region. The three metropolitan regions (Stockholm in the East, Göteborg in the 


\section{Regional effects of immigration}
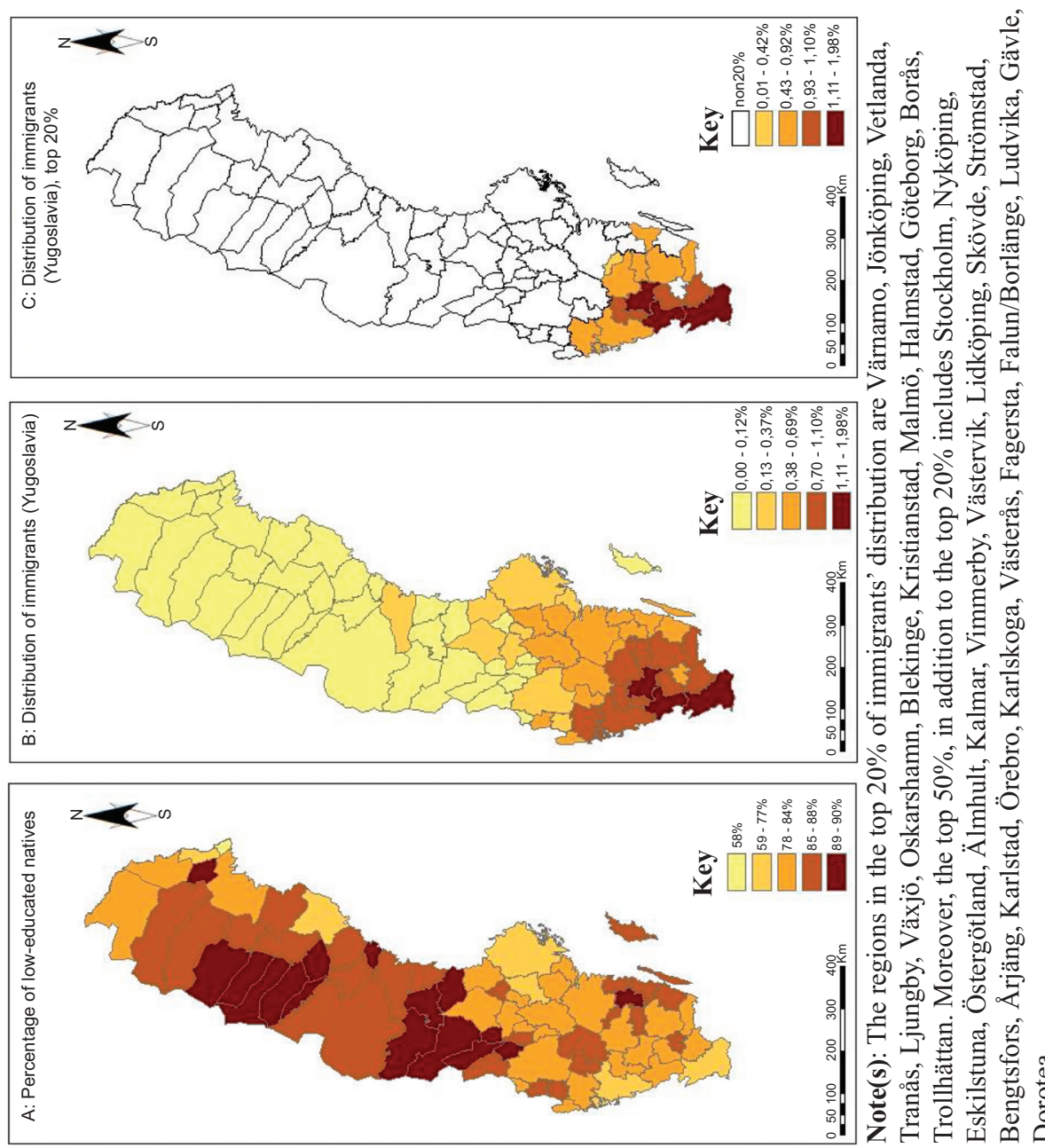

०े है

461

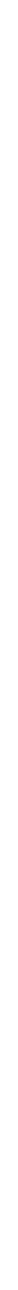

Figure 1.

Distribution of lowskilled natives $(\mathrm{A})$ and Yugoslavian-born as a percentage of regional population $(\mathrm{B}-\mathrm{C})$ 
IJSE

48,3

462

West and Malmö in the South) and other large regional centres have the lowest percentages of low-educated natives, while more sparsely populated regions in the East have higher shares.

There are several options for defining the regional shares of refugees. If we use official registers, we cannot know in which region immigrants were first distributed when seeking asylum but only where they obtained their first employment. Hence, the potential relocation between distributed location and later selected location cannot be assessed. To account for this shortcoming, we have calculated the share of Yugoslavian-born residents in each region using the 2018 official population statistics from Statistics Sweden. In so doing, we assume that the regions with high shares in 2018 were also the regions in which many Yugoslavians found employment and settled during the 1990s. Compared to using micro-data to ascribe each person a region based on their first registry in Sweden, we thereby reduce the effect of spatial relocation immediately after being assigned a residence permit. Ekberg $(1995,2011)$ showed that the reallocation effect levels off after a few years, after which time immigrants are just as likely to move as same-age natives.

\section{Variables}

Dependent variables

For the analysis, we estimate the impact of a supply shock of refugees on a panel of Swedishborn low-educated workers. We considered three main outcome variables. The first outcome variable is the monthly wage of native workers, calculated as the income from employment (pre-tax wages and salaries paid employees for time worked, excluding social security and pension contributions/benefits) and deflated using the year-on-year Swedish consumer price index (CPI), henceforth real wages. The second outcome variable is a measure of an individual's labour supply. This variable is derived from the employment status ("Sysselsättningsstatus") that Statistics Sweden uses to define an individual's labour market situation. This variable is equal to one if a worker has his/her main source of income from work a given year, and zero if otherwise (other categories are unemployed, social benefits, etc.). The third outcome variable is the measure for labour mobility. We defined this indicator by comparing the workplace identity codes for native workers at time $t$ and time $t+1$. A worker is assigned one if the workplace identity codes have changed between two years, and zero if he/she remains at the same workplace for two consecutive years. To fully understand the effects of immigration on natives' labour market outcomes, we further defined income mobility in relation to workplace change, hence addressing whether or not natives who change jobs move into a higher-income stratum (ascribed to each individual based on the national income quintile in which he/she is found). Therefore, a native is assigned the value one when he/she changed job and also moved from a lower-income stratum to a higherincome stratum (irrespective of which stratum he/she originally belonged to), and zero otherwise. With these variables, we examine whether and how native workers in regions experiencing high numbers of immigrants are affected by this potential supply shock.

\section{Treatment variables}

The main explanatory variables depict the proportion of refugees (Yugoslavians) in region $r$ and time $t$. The early 1990s saw a major influx of Yugoslavian refugees to Sweden fleeing the Balkan wars, making them a good example for this study. Based on the former Yugoslavians' share of the population in 2018, we developed a quintile distribution across the functional labour market regions (FA regions). The regions with the highest 20\% (upper quintile) of Yugoslavians are defined as the treatment group and the regions with the lowest $20 \%$ (lower quintile) are defined as the control group (see Figure 1 for the distribution of immigrants by FA region). Hence, we compare the labour market outcomes of low-educated natives in 
regions most exposed to a supply shock with those least exposed. Figure $1 \mathrm{~B}$ shows the quintile distribution, and Figure $1 \mathrm{C}$ details the top quintile, which predominantly includes the southern part of Sweden. The other key explanatory variable is a dummy for the treatment period. Because 1993 had a remarkable spike in the arrival of Yugoslavian refugees, the treatment period began in 1993. In other words, we are seeking to understand how a loweducated native in a region exposed to a sudden supply shock (treatment group) will be affected by an influx of new persons (treatment period) in terms of monthly salary, employment and labour mobility. For the purpose of leveraging the differences, we only included individuals in the top and bottom quintile regions in the analyses. Given that 1993 not only coincided with an immigration spike, but also marked the year of the deep recession that hit Sweden and increased unemployment to almost $20 \%$, we assess the worst possible scenario for labour market integration.

\section{Control variables}

The main control variables used in the analyses are sex, age, marital status, labour market experience and inter-regional mobility. Although recent studies have shown that wage differentials worldwide have fallen substantially due to the better labour market endowments of females, gender is still a concern for wage determination (Weichselbaumer and WinterEbmer, 2005). We, therefore, included a controller for sex and a controller for age, as age is a proxy for experience. We expect older workers to, on average, have higher wages than younger workers (Ours and Stoeldraijer, 2011). We also controlled for marital status, as evidence shows that entering into marriage influences hours of work and hence income (Ahituv and Lerman, 2007). Lastly, prior studies have shown the relationship between different forms of labour market experiences and wages. According to Goldsmith and Veum (2002), the return on wages is higher when the experience is from the same industry. We, therefore, marked whether the previous employer of a given person was within the same three-digit industry classification as his/her current work. It is common for workers to continue to move within and between firms within the same industry; we, therefore, expect labour market experience to positively influence both wages and mobility.

Table 1 provides descriptives for all low-educated natives for the entire period (19902003), as well as before the treatment period (1990-1992) and during the treatment period

\begin{tabular}{|c|c|c|c|c|}
\hline Variable & $\begin{array}{c}1990- \\
2003\end{array}$ & $\begin{array}{c}1990 \\
1992\end{array}$ & $\begin{array}{c}1993- \\
2003\end{array}$ & \\
\hline Real wages (monthly income) & 177.58 & 166.27 & 180.75 & \\
\hline Employment (=1 if employed, 0 otherwise) & 0.88 & 0.91 & 0.87 & \\
\hline Mobility ( $=1$ if has changed workplace, 0 otherwise) & 0.32 & 0.50 & 0.27 & \\
\hline $\begin{array}{l}\text { Mobility: high wage ( }=1 \text { if moving upwards in the wage distribution, } \\
0 \text { otherwise) }\end{array}$ & 0.31 & 0.47 & 0.27 & Table 1. \\
\hline Treatment period ( $=1$ if year $1993-2003,0$ otherwise) & 0.79 & 0.00 & 1.00 & Mean values for \\
\hline $\begin{array}{l}\text { Treatment group ( }=1 \text { if working in any of the regions with highest } \\
\text { share of refuges, } 0 \text { if working in the bottom } 20 \% \text { ) }\end{array}$ & 0.36 & 0.37 & 0.36 & $\begin{array}{l}\text { 1ncluded variables for } \\
\text { the entire study period }\end{array}$ \\
\hline Man (=1 if man, 0 otherwise) & 0.52 & 0.52 & 0.52 & $\begin{array}{l}\text { (1990-2003). Pre- } \\
\text { treatment period }\end{array}$ \\
\hline Age & 39.96 & 39.10 & 40.20 & $(1990-1992)$ and post- \\
\hline Married ( $=1$ if married, 0 otherwise) & 0.41 & 0.41 & 0.40 & treatment period \\
\hline $\begin{array}{l}\text { Labour market experience ( }=1 \text { if has experience in the same three-digit } \\
\text { industry) }\end{array}$ & 0.05 & 0.04 & 0.06 & $\begin{array}{l}\text { (1993-2003). Low- } \\
\text { educated native }\end{array}$ \\
\hline Population (population size in region, 1,000 s) & 171.19 & 158.35 & 174.65 & workers only \\
\hline$N$ & $1,033,028$ & 244,465 & 788,563 & $(N=1,033,028)$ \\
\hline
\end{tabular}


IJSE

48,3

(1993-2003). As shown in the table, real wages generally increase during the treatment period (post-1993) for all low-skilled natives, while employment and both types of mobility decrease on average. For pair-wise correlations, consult Table A1 in Appendix.

\section{Empirical model}

The empirical model employed in the empirical analysis is a difference-in-differences model (cf. Card and Kreuger, 1994), which is a statistical technique that mimics an experimental research design by studying the differential effects of a treatment on a treatment group vs a control group. Difference-in-differences calculates the effects of a treatment (explanatory variables) on an outcome (response variable) by comparing the average change over time in the outcome variable for the treatment group, compared to the average change over time for the control group. Essentially what difference-in-differences does in the present case is to take the average change in the outcome variable (real wage, employment, mobility) of the control group from 1990 to 2003 and the average change in the same outcome variable of the treatment group from 1990 to 2003 and highlight the differences between the groups defined above. Consequently, we are able to estimate the average changes in the respective outcome variable for low-educated native workers in regions characterised by low shares of Yugoslavian refugees compared to those for low-educated native workers in regions characterised by high shares of refugees before and after the supply shock in 1993. The idea behind difference-in-differences estimation is that it allows us to control for many other factors that might cause endogeneity. An alternative would be to employ propensity score matching to identify the "statistical twin" of each low-skilled native in high-immigration regions. However, as our treatment group indicator is the region of work, and not the individual per $s e$, it is difficult to find observable regional indicators that can effectively explain why a certain labour market region receives high- or low-shares of refugees. Hence, like Card (2001) did, we resort to a spatial difference-in-differences approach as follows:

$$
\mathrm{NAT}_{r t}=\beta_{0}+\beta_{1}[\mathrm{TY}]+\beta_{2}[\mathrm{TG}]+\beta_{3}[\mathrm{TY} \times \mathrm{TG}]+\beta_{4}[\text { Control }]+\varepsilon_{r t}
$$

$\mathrm{NAT}_{r t}$ in equation (1) are the outcome variables (real wage, employment and labour mobility) for low-skilled native workers in region $r$ at time $t$. $\beta_{0}$ is the baseline average, $\beta_{1}$ is the coefficient of the dummy for treatment period (1993 onwards) and $\beta_{2}$ is the coefficient of the dummy for the treatment group (low-educated natives in immigration rich regions). $\beta_{3}$ is the coefficient of the interaction between treatment time and group, which captures the difference in the differences over time of working in a region exposed to high relative numbers of refugees. $\beta_{4}$ is a vector of coefficients of control variables (i.e. sex, age, marital status, industry experience and regional mobility), and $\varepsilon_{r t}$ is the error term. We also included fixed effects for year (to control for unobserved heterogeneity related to time, e.g. recession or policy changes), 87 industry dummies at the two-digit level (to control for technological differences, and variations in business cycles and income levels), 72 regional dummies capturing functional labour markets (controlling unobserved regional differences) and finally, 45 different educational fields to characterise each worker, thus making use of the information of direction of education in the data (to assess differences in formal skills).

Although income is the sole continuous variable, while employment and mobility are binary variables, we applied an ordinary least squares (OLS) regression on all variables. Hence, employment and the two mobility variables are linear probability models. Although the standard approach would be to use logit or probit functions on these variables, the main rationale for using this type of model is that it facilitates comparison across models and allows interactions, something that is generally difficult in a logit or probit setting (see Mood, 2010; Wooldridge, 2002, for extensive discussions on the pros and cons of linear probability models). 
We also used the panel structure of the dataset in a fixed-effect estimation on natives' labour market outcomes. An important feature of this approach is that it uses the panel structure of the data by accounting for within transformation and for unobserved heterogeneity among individual workers (e.g. unobserved ability or aspiration). The problem with this particular model is that it cannot handle time-invariant variables (i.e. treatment group), and hence, it was only estimated as a robustness check.

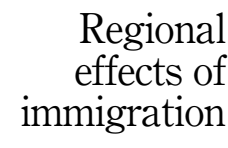

465

\section{Results}

Over the years, Sweden has been a destination for economic and political migrants. With the exception of Nordic immigrants, all other immigration categories have consistently shown the tendency to increase, especially immigrants from other parts of Europe. The inflow of Yugoslavians (Serbia, Croatia, Montenegro, Kosovo, Slovenia, Bosnia, Herzegovina, Macedonia) to Sweden began with the migrant work agreement signed between Sweden and the Yugoslav government in the 1960s to deal with the severe labour shortage in primarily the manufacturing sectors. The Balkan war in the early 1990s saw another influx to Sweden, first, with the arrival of refugees and, second, with family reunification. In all, about 110,000 persons from the former Yugoslavia applied for asylum during this period. Despite this unpreceded influx of refugees to Sweden, which coincided with a deep recession, as a group these immigrants did relatively well on the labour market, showing high employment rates (Ekberg, 2016). For this reason, the potential competition for available jobs intensified, which may have had adverse effects for low-skilled natives.

Similar to what is shown in Table 1, Figures 2 and 3 map the means of each dependent variable (left) before the treatment period (1990-1992) and the respective change before and after treatment (1993 onwards) to the right. The highest incomes for low-educated workers are found in Stockholm (East) and Gothenburg (West), but also in the mining regions in the very north. Moreover, employment rates are far higher in, and around, the three largest regions in the south, and due to the ongoing recession, the employment figures for loweducated workers also worsened in all regions, but less severely so in the southern parts of Sweden (many of which belong to the treatment group of regions). This regional pattern of wages and employment can be contrasted with mobility, as general mobility is mainly higher in the northern part of the country and upward wage mobility more evenly distributed.

Figure 4 shows the employment shares for all natives, irrespective of educational level (A), and all low-educated native workers (B) before the supply shock in 1993 and after the supply shock 1993-2003 (treatment period), based on their position in the wage distribution (five groups equal in size, low to high, left to right). While the distribution of natives overall is largely unaffected over time (A), we find signs of a moderate upgrade for low-educated natives. Although the share is increasing in all income groups, this is particularly true for income Groups 2, 3 and 4.

So, while the descriptive evidence indicates a slight upward trend in the share of loweducated natives' relative position in the wage distribution after the supply shock, we still have not assessed whether this is the case in a multivariate setting. Consequently, we turn our attention to Table 2. The main variable of interest in this table is the interaction between treatment period and treatment group (coefficient $\beta_{3}$ in equation (1)). Models 1, 2, 3 and 4, respectively, indicate the association between immigration and low-educated native workers' real wages (1), employment (2), mobility (3) and mobility into higher income job (4).

Controlling for individual, sectorial and regional attributes, the estimates show that loweducated workers in immigration-rich regions (treatment group) have positive wage development, but also that the treatment period in general is associated with increasing incomes. Concerning employment (model 2), the treatment period that also is associated with a recession has a general negative association with employment. This is expected, as the 
IJSE

48,3

466
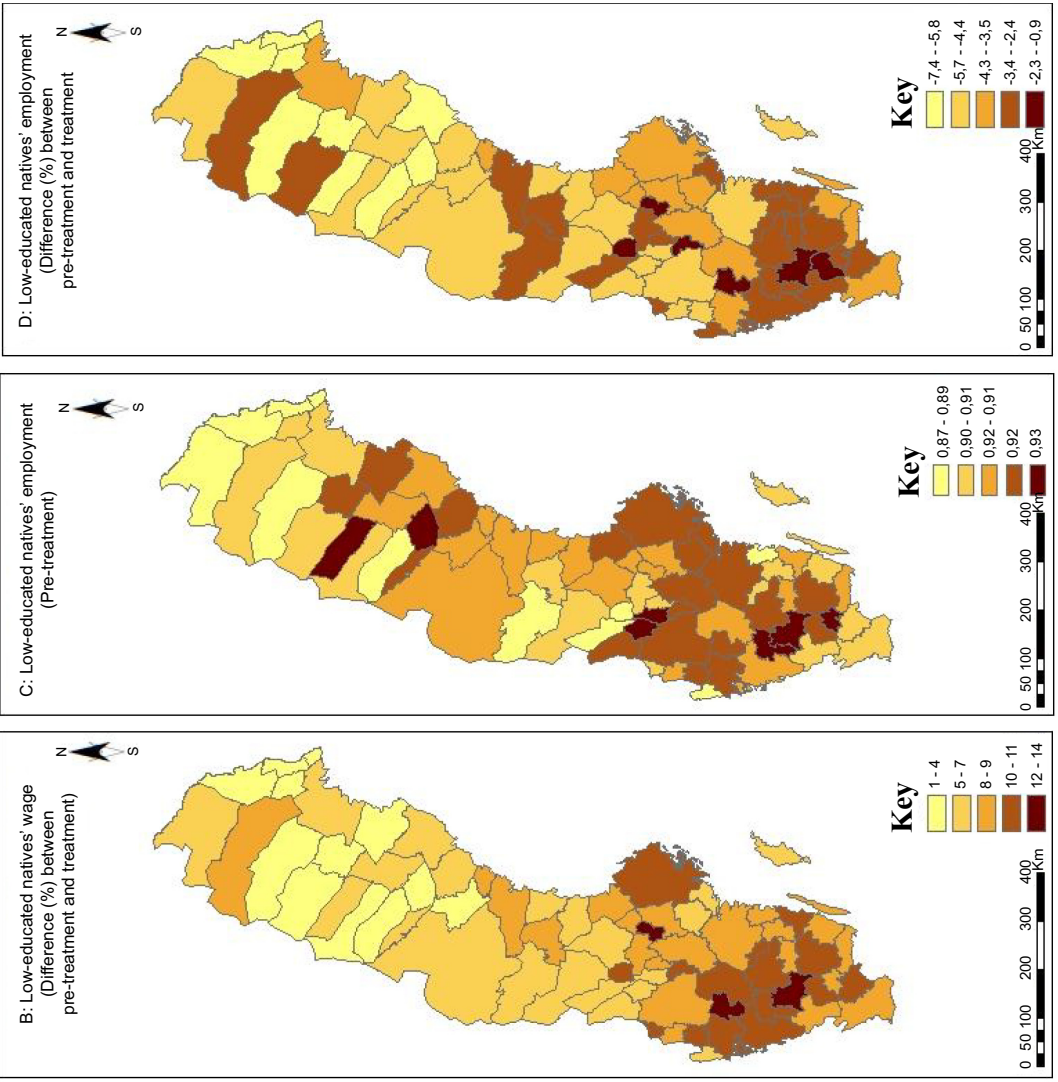

Figure 2.

Low-educated natives' wage (A-B) and employment (C-D) before 1993 (pretreatment) and difference between the 1990-1992 and 19932003 periods (B and $\mathrm{D}$ )

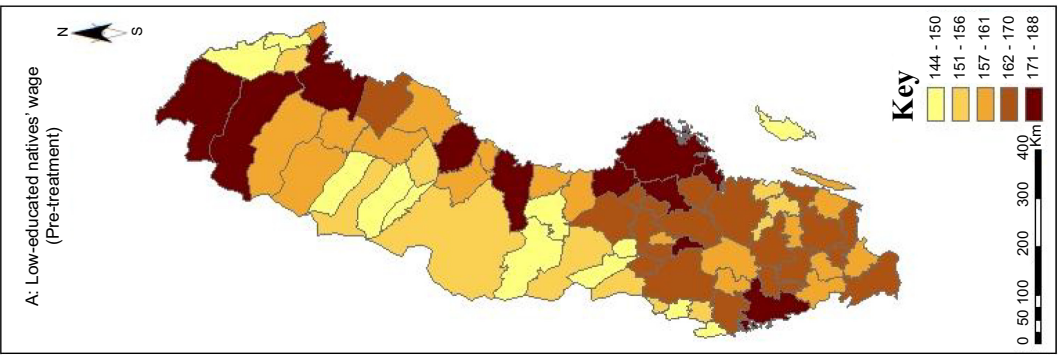




\section{Regional effects of immigration}
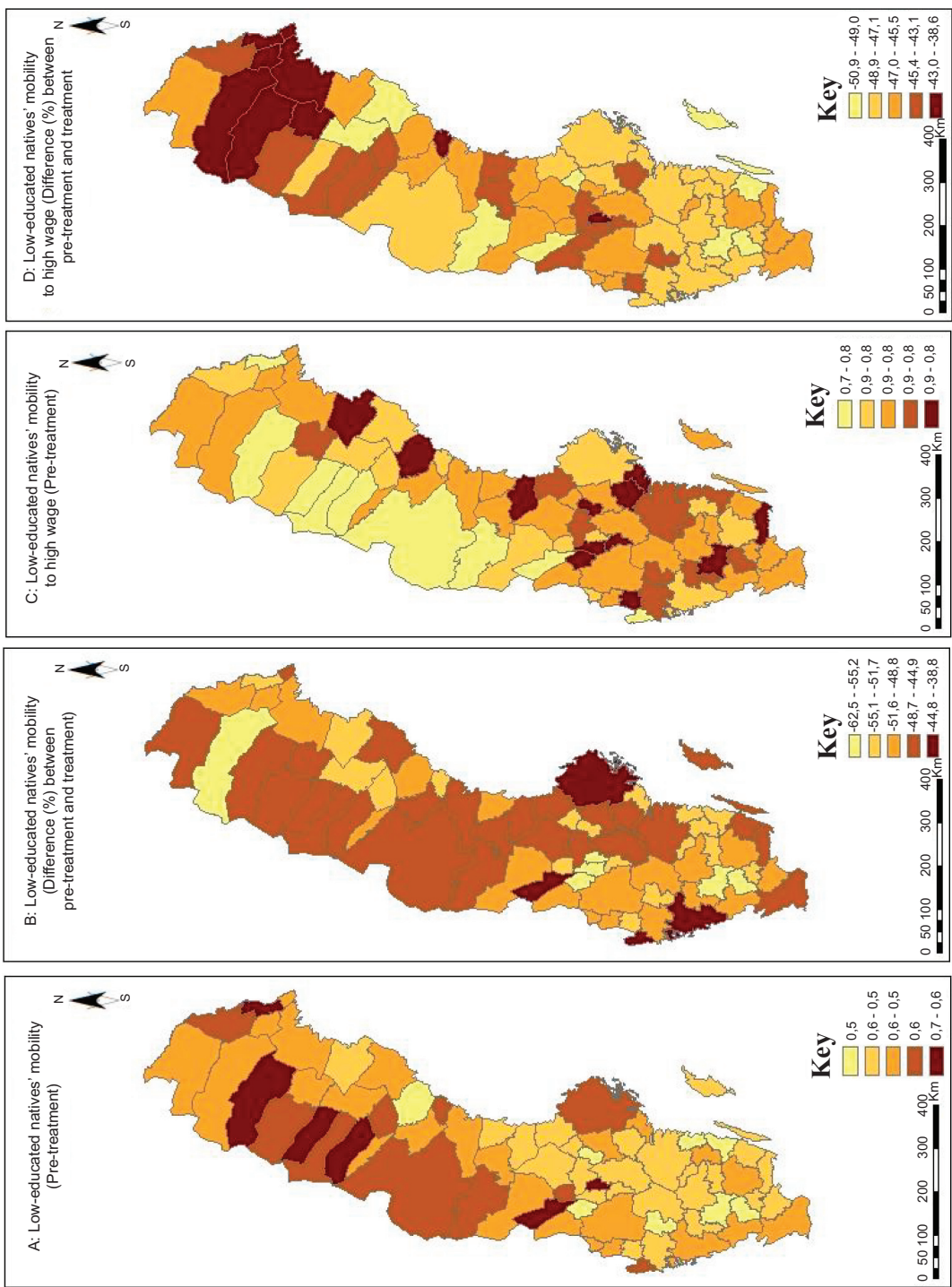

Figure 3.

Low-educated natives' job mobility (A-B) and mobility to a higherincome stratum (C-D) before 1993 (pretreatment) and difference between the 1990-1992 and 19932003 periods (B and D) 
IJSE

48,3

468

recession in general influenced the working prospects of particularly low-skilled workers (Eriksson and Hane-Weijman, 2017). Our data also support the idea that low-educated natives are more likely to obtain gainful employment in more immigration-exposed regions. However, we cannot find any evidence to show that low-skilled native workers respond to the inflow of low-skilled immigrants by changing workplace (model 3), as the interaction term is insignificant at the same time as the main effects of both treatment period and group are significantly negative. However, for the low-skilled natives who do change workplace, this mobility could of course both be due to complementary as well as substitution effects, as some native workers either are crowded out and need to look for new employment or move to new, better paid jobs. The former process is confirmed in model 4, as the upward mobility of workers is less likely to occur during the treatment period in general, but particularly so in the treatment regions.

Our findings showing that the income development of low-educated natives is relatively favourable after the supply shock, which is in contrast to previous findings identifying negative (e.g. Borjas, 2003; Dustmann et al., 2017; Angrist and Kugler, 2003) or negligible (e.g. González and Ortega, 2011; Manacorda et al., 2012) effects of immigration on natives. In turn, we find support for previous findings, suggesting that low-skilled natives transition into high-wage jobs (e.g. Foged and Peri, 2015; Peri and Sparber, 2009; Ortega and Verdugo, 2014). One reason could be that native workers have specialised more in communication-intensive tasks than have immigrants, as suggested by Foged and Peri (2015) and Peri and Sparber (2009).

\section{Robustness checks}

To determine the validity of our results, we have estimated a number of alternative models. First, we estimated logit models on employment and mobility to validate the use of linear probability models, because the chosen approach also has certain shortcomings (e.g. probabilities not bounded between 0 and 1). The main results (signs and significance) of the different treatment variables remained, with one exception: The interaction of treatment year and treatment group in model 3 on job mobility turned positive (but remained insignificant) in a logit setting. Hence, we can confidently argue that the main tendencies reported in Table 2 remain robust, even when not employing linear probability models. Second, as the labour market prospects could be different in different types of regions, particularly in more expanding economies (Tabellini, 2020), we made an initial interaction with population size, assuming that larger regions are more likely to better absorb new workers (Table 3). Indeed, the mobility to higher-income segments is more likely to occur in large treatment regions compared smaller ones. However, we cannot find any support for the notion that income development, employment or mobility is more likely to occur in larger regions subject to high immigration shares compared to smaller regions. This would rather suggest a transformation

Figure 4.

Employment shares ( $y$-axis) of all natives (A) and low-educated natives (B) divided into five income groups (1-5 on $x$-axis) pre-treatment period (1990-1992) and during treatment period (1993-2003)
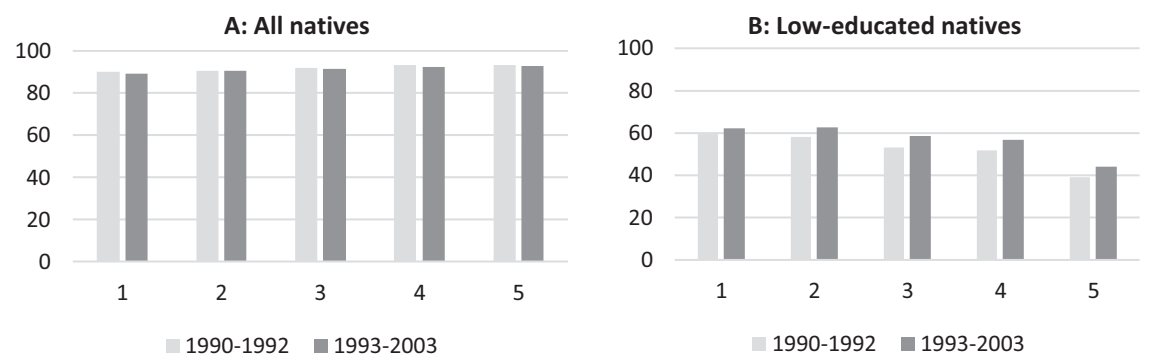


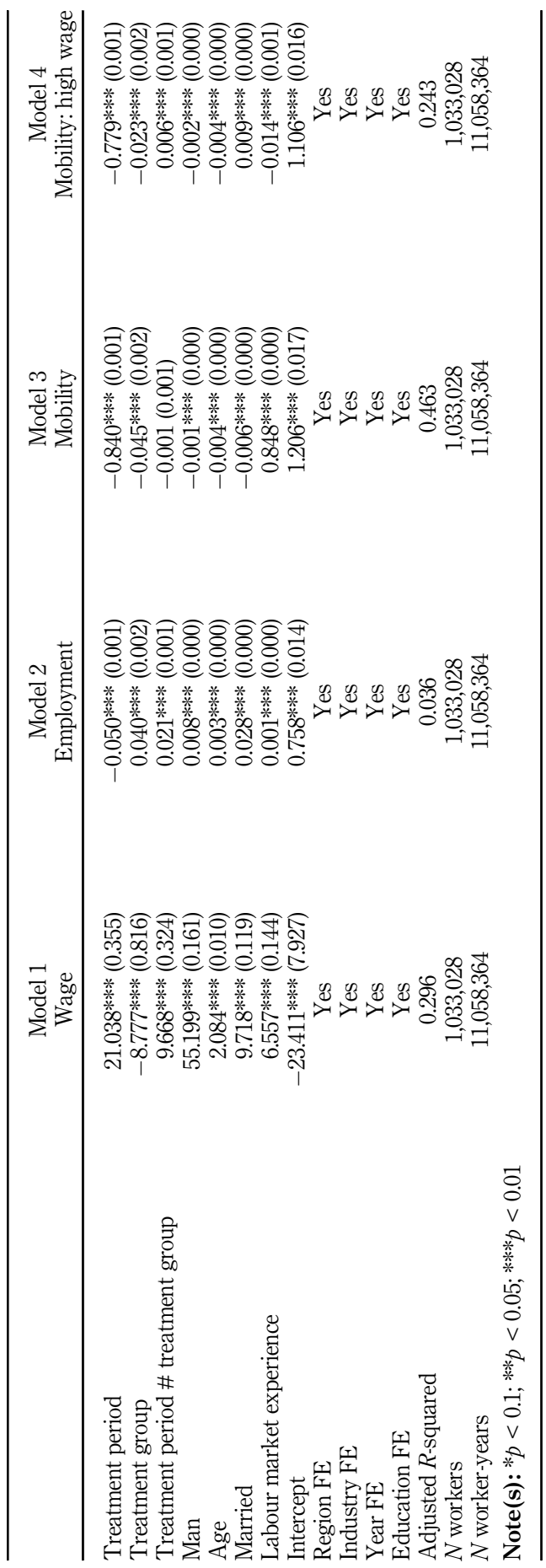

Table 2.

OLS models on the influence of immigration on loweducated native workers' labour market outcomes 


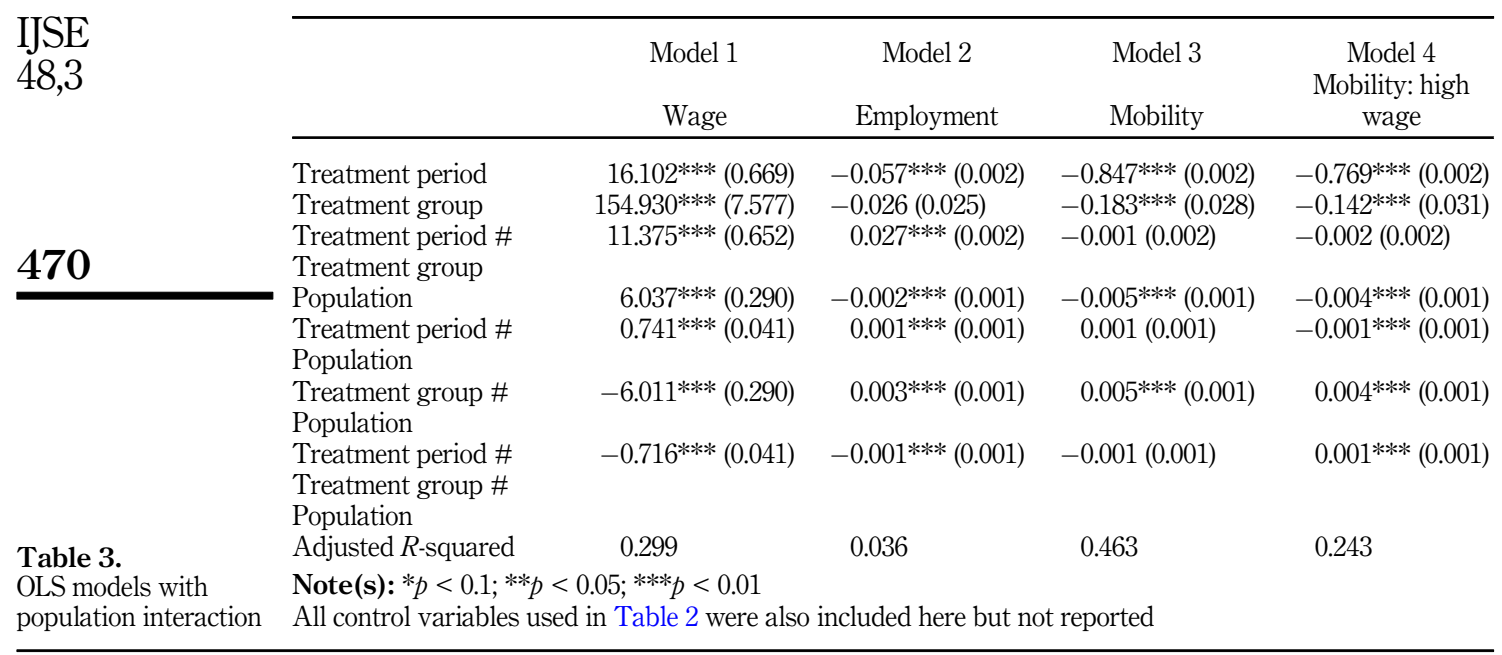

processes in which low-skilled jobs with relatively high-income levels (e.g. in manufacturing) were phased out in the larger regions while still present in smaller treatment regions.

Third, to understand the full effects of immigration on low-skilled natives' labour market outcomes, we expanded the treatment group in Table 4 to include the top $50 \%$ of all regions that received Yugoslavians (panel A). We also redefined the dependent variable to include all natives and not only low-skilled ones (panel B), and then in panel C altered the treatment group based on the regions housing the greatest share of all non-EU immigrants (from Africa, Asia, Latin America, CEE countries and the former Soviet Union). The results are similar in significance and direction to our main findings, but the wage effect when expanding the treatment groups is slightly higher, as is the probability of changing workplace and moving upwards in the wage distribution. When estimating the influence on all natives, the findings are still similar, yet with slightly higher-income effects. The effects on employment and the two types of mobility, however, are slightly weaker (if at all present), which is reasonable as the entire sample of Swedish-born workers should be less affected by immigration due to the different labour market segments they presumably are operating in (see, e.g. the descriptives in Figure 4). Finally, because Yugoslavians are used in principle as a proxy to model in detail the labour market consequences of immigration on low-skilled native workers, panel C estimates the effect on low-skilled native workers in the top $20 \%$ of all regions with the highest immigration shares, compared to the bottom $20 \%$ of immigration shares. Again, the main findings are supported. Low-skilled native workers in immigration-rich regions are more likely to experience better income development, be in employment and change workplace while also moving upwards in the wage hierarchy.

Fourth, for the purposes of testing the validity and consistency of the estimations from equation (1), we estimated a fixed-effect model to account for unobserved worker heterogeneity, such as abilities and ambition. Table 5 presents the results when considering the within transformation, which largely confirm the findings presented in Table 2. The coefficient on low-educated native workers' real wages is, however, relatively smaller when considering year-to-year differences and unobserved worker characteristics. However, apart from also increasing the likelihood of changing workplace, the fixed-effect model suggests a higher likelihood of moving upwards in the wage distribution. 


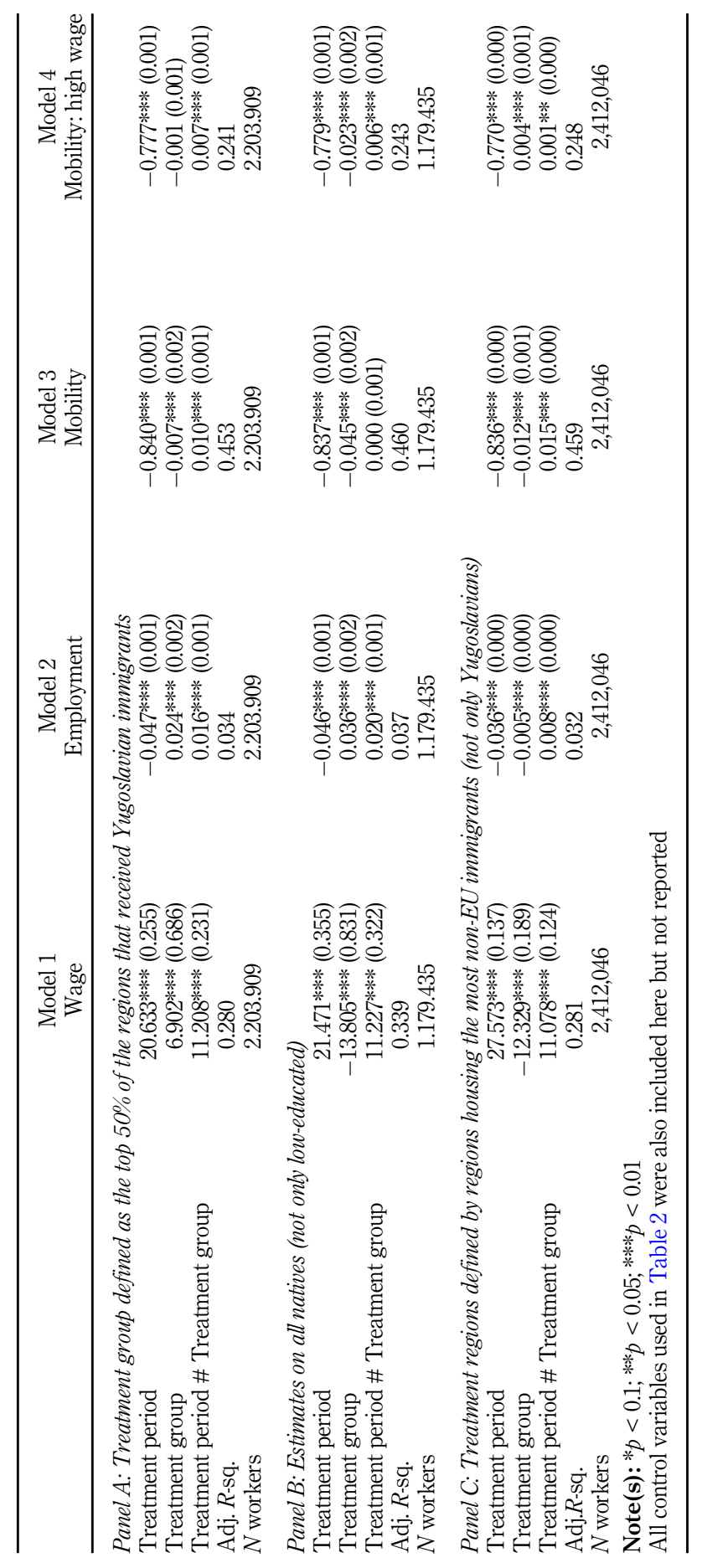

Table 4.

OLS models on the top $50 \%$ (up). All natives (middle) and all non-EU immigrants (bottom) 


\begin{tabular}{|c|c|c|c|c|c|}
\hline 48,3 & & $\begin{array}{l}\text { Model } 1 \\
\text { Wage }\end{array}$ & $\begin{array}{c}\text { Model } 2 \\
\text { Employment }\end{array}$ & $\begin{array}{l}\text { Model } 3 \\
\text { Mobility }\end{array}$ & $\begin{array}{l}\text { Model } 4 \\
\text { Mobility: high } \\
\text { wage }\end{array}$ \\
\hline 472 & $\begin{array}{l}\text { Treatment period } \\
\text { Treatment group } \\
\text { Treatment period \# } \\
\text { treatment group }\end{array}$ & $\begin{array}{r}12.962 * * *(0.918) \\
-8.031 * * *(2.724) \\
7.875^{* * *}(0.298)\end{array}$ & $\begin{array}{l}0.001(0.004) \\
0.015(0.012) \\
0.020 * * *(0.001)\end{array}$ & $\begin{array}{c}-0.632 * * *(0.006) \\
0.010(0.013) \\
0.007 * * *(0.001)\end{array}$ & $\begin{array}{l}-0.591 * * *(0.008) \\
0.000(0.011) \\
0.010 * * *(0.001)\end{array}$ \\
\hline $\begin{array}{l}\text { Table } 5 . \\
\text { Fixed-effect models }\end{array}$ & \multicolumn{5}{|c|}{$\begin{array}{l}\text { Note(s): } * p<0.1 ; * * p<0.05 ; * * * p<0.01 \\
\text { All control variables used in Table } 2 \text { were also included here but not reported }\end{array}$} \\
\hline
\end{tabular}

Fifth, studies have shown that there is significant income increase caused by inter-regional labour mobility (e.g. Lehmer and Möller, 2008; Nakosteen and Westerlund, 2004). We, therefore, split the sample in two groups: one that migrates to another region (panel A) and one that remains in the same region throughout the study period (panel B). The results (Table 6) do indeed show that movers tend to be better off than stayers, as the income change is almost twice as large for movers as for stayers, and the estimates on both employment and upward wage mobility are almost three times larger for movers than for stayers.

\section{Conclusions}

The aim of the present paper was to assess how immigration affects low-educated natives' real wages, employment and income mobility. Using Swedish longitudinal data, we analysed the immigration of refugees from the former Yugoslavia following the Balkan war in the early 1990s. Although this coincided with a period of recession, previous studies have identified the remarkable labour market success of these immigrants relative to other immigration waves (Ekberg, 2016). However, we have very limited knowledge about whether this relative labour market success also implied a crowding-out effect of native workers, as the scarcity of jobs was relatively low.

Despite the general assumption that immigration imposes an adverse effect on native workers' wage and employment opportunities, our most robust finding was that loweducated native workers responded to the inflow of immigrants with an increase in real

\begin{tabular}{|c|c|c|c|}
\hline & $\begin{array}{l}\text { Model } 1 \\
\text { Wage }\end{array}$ & $\begin{array}{c}\text { Model } 2 \\
\text { Employment }\end{array}$ & $\begin{array}{c}\text { Model } 4 \\
\text { Mobility: high wage }\end{array}$ \\
\hline \multicolumn{4}{|l|}{ Panel A: Movers } \\
\hline Treatment period & $-47.542^{* * * *}(0.941)$ & $-0.272 * * *(0.004)$ & $-0.333 * * *(0.004)$ \\
\hline Treatment group & $0.757(0.898)$ & $0.046 * * *(0.004)$ & $-0.038 * * *(0.003)$ \\
\hline Treatment period \# treatment group & $16.403 * * *(0.664)$ & $0.049 * * *(0.003)$ & $0.050 * * *(0.003)$ \\
\hline Adjusted $R$-squared & 0.272 & 0.118 & 0.389 \\
\hline \multicolumn{4}{|l|}{ Panel B: Stayers } \\
\hline Treatment period & $32.873 * * *(0.365)$ & $-0.023 * * *(0.001)$ & $0.054 * * *(0.002)$ \\
\hline Treatment group & $-11.544 * * *(0.864)$ & $0.036 * * *(0.002)$ & $-0.017 * * *(0.002)$ \\
\hline Treatment period \# treatment group & $8.351 * * *(0.338)$ & 0.016 *** $(0.001)$ & $0.015 * * *(0.002)$ \\
\hline Adjusted $R$-squared & 0.307 & 0.029 & 0.018 \\
\hline
\end{tabular}

Table 6.

Effects of immigrants on native movers and stayers
Note(s): $* p<0.1 ; * p<0.05 ; * * * p<0.01$

All control variables used in Table 2 were also included here but not reported. Workplace change is omitted because all migrants have also changed workplace 
wages. This was, however, mainly driven by a slow, but steady, increase in real wages after the deep recession. Nevertheless, this finding does support the argument that the arrival of immigrants might cause, in the short to medium term, a downward pressure on real wages and employment of natives with competing skills (e.g. Aydemir and Borjas, 2011; Edo, 2015). Second, our analysis shows no clear evidence of a significant decline or reduction in employment of low-educated natives. On the contrary, the year-on-year analysis shows that natives respond to immigration with an increase in employment. Third, low-educated natives in immigration-rich regions are more likely to change job. Whether this mobility leads to upgrading or crowding out depends on the regional context. In smaller regions, job mobility seems to be associated with a lower probability of moving upwards in the wage distribution (despite a general positive effect of real wages). By contrast, in larger regions, this mobility is associated with upward mobility into a higher-income group. Hence, from a regional perspective, this supports the claim that in economies with relative capital adjustment (expansion), upgrading is more likely, while the pressure on real wages increases in less expanding markets (Tabellini, 2020). Hence, in expanding markets, low-educated natives are more likely to respond to the arrival of immigrants by leaving their former job (e.g. Foged and Peri, 2015; Peri and Sparber, 2009). In effect, the arrival of immigrants is likely to force lowskilled natives to upgrade their skill portfolio.

The findings of the present study have some implications for policy. First, apart from immigration fuelling economic growth, it must also be noted that the arrival of immigrants has an overall positive effect on native workers in the long term. Therefore, the findings presented here refute some of the rhetoric on more recent years' waves of refugee immigration, according to which the arrival of refugees only induces negative effects on real wages and heighten risk of unemployment. Second, if the arrival of immigrants is likely to induce negative effects on real wages and heighten risk of unemployment among loweducated native workers in the short term, as suggested in other studies (e.g. Aydemir and Borjas, 2011; Borjas, 2003), policies should aim at income redistribution to curtail the effects of wage fall and risk of unemployment rather than at impeding immigration. Finally, as immigration is part of human existence, migration policies ought to be reformed with the intent of encouraging higher education or skill specialisation to shorten the period of shortterm wage fall and risk of unemployment. This is particularly important because recent studies suggest that the correlation of an expanding low-wage sector and refugee immigration is the highest in countries with low potential for social mobility and low rates of investment (Andersson et al., 2019).

In summary, we have presented a detailed analysis of the regional effects of immigration on low-skilled native workers. This is important because the proportion of immigrants is seldom evenly distributed across a nation. It is, therefore, not very likely that a low-skilled native worker will respond to a supply shock of immigrants in another part of the country. Instead, these effects tend to be more local. The present analyses have, in this regard, presented a more comprehensive picture of the impacts of immigration by tracking the labour market effects on natives' real wages, employment and job mobility. We hope that future analyses of the impact of immigration will consider multiple labour market outcomes and both short- and long-term effects.

\section{References}

Ahituv, A. and Lerman, R. (2007), "How do marital status, work effort, and wage rates interact?", Demography, Vol. 44 No. 3, pp. 623-647.

Altonji, J. and Card, D. (1991), "The effects of immigration on the labor market outcomes of less-skilled natives", in Abowd, J. and Freeman, R. (Eds), Immigration, Trade, and the Labor Market, University of Chicago Press, Chicago, pp. 201-234.

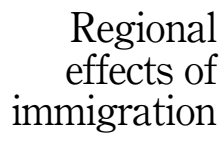

473 
IJSE

48,3

Andersson, L.F., Eriksson, R.H. and Scocco, S. (2019), "Refugee immigration and the growth of low-wage work in the EU15”, Comparative Migration Studies, Vol. 7, p. 39, doi: 10.1186/s40878-019-0145-3.

Angrist, J.A. and Kugler, A.D. (2003), "Protective or counter-productive? Labor market institutions and the effect of immigration on EU natives", The Economic Journal, Vol. 113 No. 488, pp. 302-331.

Aydemir, A. and Borjas, G.J. (2011), "Attenuation bias in measuring the wage impact of immigration", Journal of Labor Economics, Vol. 29 No. 1, pp. 69-112.

Borjas, G. (1987), "Self-selection and the earnings of immigrants", The American Economic Review, Vol. 77 No. 4, pp. 531-553.

Borjas, G. (2003), "The labor demand curve curve is downward sloping: reexamining the impact of immigration on the labour market", The Quarterly Journal of Economics, Vol. 118 No. 4, pp. 1335-1374.

Borjas, G. (2006), "Native internal migration and the labor market impact of immigration”, The Journal of Human Resources, Vol. 41 No. 2, pp. 221-258.

Borjas, G.J. (2014), Immigration Economics, Harvard University Press, Cambridge (Mass).

Bratsberg, B., Raaum, O., Roed, M. and Schone, P. (2014), "Immigration wage effects by origin", The Scandinavian Journal of Economics, Vol. 116 No. 2, pp. 356-393.

Card, D. (2009), "Immigration and inequality", American Economic Review, Vol. 99 No. 2, pp. 1-21.

Card, D. (2001), "Immigrant inflows, native outflows, and the local labor market impacts of higher immigration”, Journal of Labor Economics, Vol. 19 No. 1, pp. 22-64.

Card, D. and Krueger, A. (1994), "Minimum wages and employment: a case study of the fast-food industry in New Jersey and Pennsylvania", The American Economic Review, Vol. 84 No. 4, pp. 772-793.

D'Amuri, F. and Giovanni, P. (2011), "Immigration, jobs and employment protection: evidence from Europe”, NBER Working Paper Series WP: 17139.

Dustmann, C., Schönberg, U. and Stuhler, J. (2016), “The impact of immigration: why do studies reach such different results?”, The Journal of Economic Perspectives, Vol. 30 No. 4, pp. 31-56.

Dustmann, C., Schönberg, U. and Stuhler, J. (2017), "Labor supply shocks, native wages, and the adjustment of local employment", The Quarterly Journal of Economics, Vol. 132 No. 1, pp. 435-483.

Edo, A. (2015), "The impact of immigration on native wages and employment", The B.E. Journal of Economic Analysis and Policy, Vol. 15 No. 3, pp. 1151-1196.

Edo, A. (2019), "The impact of immigration on the labor market", Journal of Economic Surveys, Vol. 33 No. 3, pp. 922-948.

Ekberg, J. (1995), "Internal migration among immigrants in Sweden", in Lundh, C. (red.), A Longitudinal Study«, kapitel $i$ Demography, Economy and Welfare, Lund University Press, Lund.

Ekberg, J. (2011), "Will future immigration to Sweden make it easier to finance the welfare system?", European Journal of Population, Vol. 27 No. 1, pp. 103-124, doi: 10.1007/s10680-010-9227-5.

Ekberg, J. (2016), “Det finns framgångsrika flyktingar på arbetsmarknaden”, Ekonomisk debatt, Vol. 44 No. 5 , pp. 6-11.

Eriksson, R.H. and Hane-Weijman, E. (2017), "How do regional economies respond to crises? The geography of job creation and destruction in Sweden (1990-2010)", European Urban and Regional Studies, Vol. 24 No. 1, pp. 87-103, doi: 10.1177/0969776415604016.

Foged, M. and Peri, G. (2015), "Immigrants' effect on native workers: new analysis on longitudinal data", American Economic Journal: Applied Economics, Vol. 8 No. 2, pp. 1-34.

Goldsmith, A. and Veum, J. (2002), "Wages and the composition of experience", Southern Economic Journal, Vol. 69 No. 2, pp. 429-443. 
González, L. and Ortega, F. (2011), "How do very open economies adjust to large immigration flows? Evidence from Spanish regions", Labour Economics, Vol. 18 No. 1, pp. 57-70, doi: 10.1016/j. labeco.2010.06.001.

Lehmer, F. and Möller, J. (2008), "Group-specific effects of inter-regional mobility on earnings - a microdata analysis for Germany”, Regional Studies, Vol. 42 No. 5, pp. 657-674, doi: 10.1080/ 00343400701543686.

Lewis, E. (2011), "Immigration, skill mix, and capital skill complementarity", Quarterly Journal of Economics, Vol. 126 No. 2, pp. 1029-1069, doi: 10.1093/qje/qjr011.

Manacorda, M., Manning, A. and Wadsworth, J. (2012), "The impact of immigration on the structure of wages: theory and evidence from Britain", Journal of the European Economic Association, Vol. 10 No. 1, pp. 120-151.

Mood, C. (2010), "Logistic regression: why we cannot do what we think we can do and what we can do about it", European Sociological Review, Vol. 26 No. 1, pp. 67-82.

Nakosteenl, R. and Westerlund, O. (2004), "The effects of regional migration on gross incomes of labour in Sweden”, Papers in Regional Science, Vol. 83 No. 3, pp. 581-595, doi: 10.1007/s10110004-0209-z.

Ortega, J. and Verdugo, G. (2014), "The impact of immigration on the French labor market: why so different?", Labour Economics, Vol. 29, pp. 14-27, doi: 10.1016/j.labeco.2014.05.002.

Ottaviano, G. and Peri, G. (2012), "Rethinking the effect of immigration on wages", Journal of the European Economic Association, Vol. 10 No. 1, pp. 152-197, doi: 10.1111/j.1542-4774.2011.01052.x.

Ours, J. and Stoeldraijer, L. (2011), “Age, wage and productivity in Dutch manufacturing”, De Economist, Vol. 159 No. 1, pp. 113-137, doi: 10.1007/s10645-011-9159-4.

Peri, G. (2012), "The effect of immigration on productivity: evidence from U.S. states", The Review of Economics and Statistics, Vol. 94 No. 1, pp. 348-358.

Peri, G. and Sparber, C. (2009), "Task specialization, immigration, and wages", American Economic Journal: Applied Economics, Vol. 1 No. 3, pp. 135-169.

Roy, A. (1951), "Some thoughts on the distribution of earnings", New series, Oxford Economic Papers, Vol. 3 No. 2, pp. 135-146.

SCB (2019a), "Arbetslösheten minskade bland inrikes födda”, available at: https://www-scb-se.proxy. ub.umu.se/hitta-statistik/statistik-efter-amne/arbetsmarknad/arbetskraftsundersokningar/ arbetskraftsundersokningarna-aku/pong/statistiknyhet/arbetskraftsundersokningarna-akuarsmedeltal-2018/ (accessed 22 February 2019).

SCB (2019b), "Population", available at: https://www-scb-se.proxy.ub.umu.se/hitta-statistik/statistikefter-amne/befolkning/befolkningens-sammansattning/befolkningsstatistik/\#_Nyckeltal (accessed 22 February 2019).

Tabellini, M. (2020), "Gifts of the immigrants, woes of the natives: lessons from the age of mass migration", Review of Economic Studies, Vol. 87 No. 1, pp. 454-486.

Weichselbaumer, D. and Winter-Ebmer, R. (2005), "A meta-analysis of the international gender wage gap”, Journal of Economic Surveys, Vol. 19 No. 3, pp. 479-511.

Wooldridge, J.M. (2002), Econometric Analysis of Cross Section and Panel Data, MIT Press, Cambridge, Massachusetts.

\section{Corresponding author}

Rikard H. Eriksson can be contacted at: rikard.eriksson@umu.se

Regional effects of immigration 


\section{IJSE \\ 48,3 \\ Appendix}

476

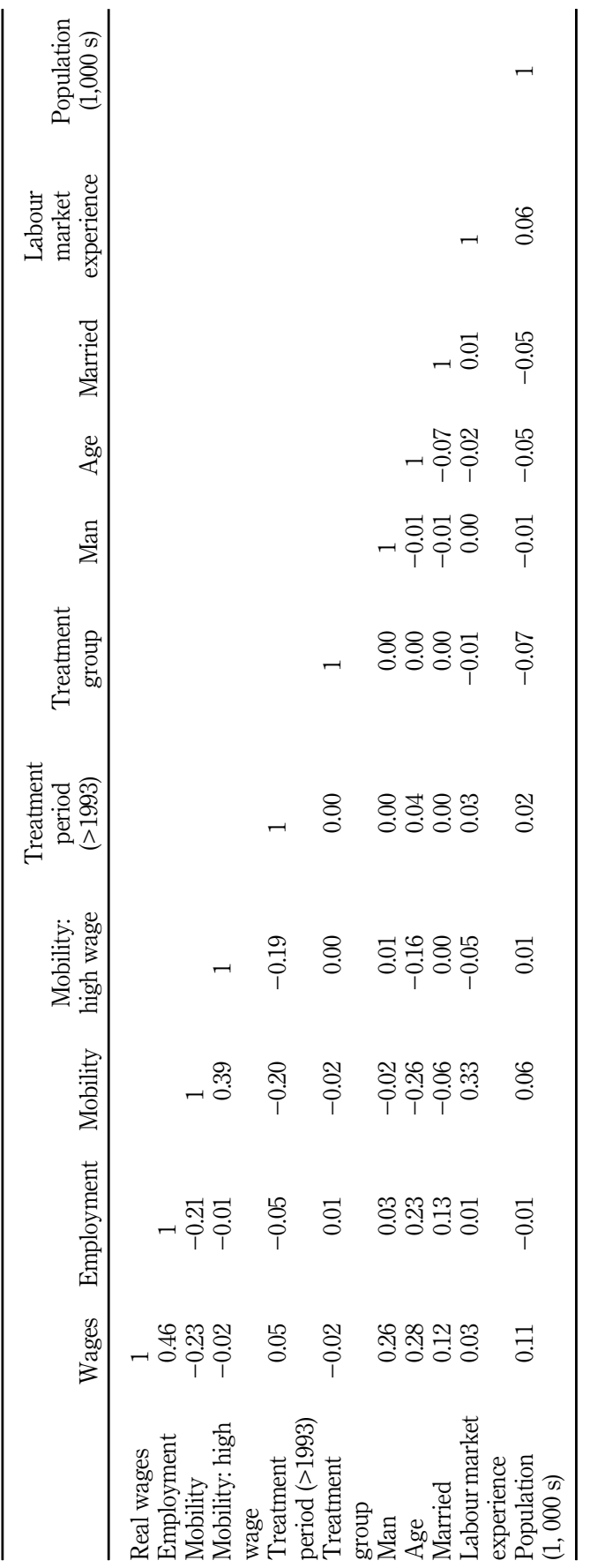

Table A1.

Correlation matrix 